\title{
Uji Antifungi Ketepeng Cina (Cassia alata L.) Terhadap Trichophyton rubrum Dan Candida albicans
}

\author{
Qurrotu A'yunin Lathifah ${ }^{1}$, Eka Puspitasari ${ }^{1}$, Dora Dayu Rahma Turista ${ }^{1}$ \\ ${ }^{1)}$ Prodi D3 Teknologi Laboratorium Medis, STIKes Hutama Abdi Husada Tulungagung \\ 21ayunin@gmail.com
}

Tanggal Submit:

Tanggal Review:

22 Februari 2021

Tanggal Publish

Online: 18 Juni 2021
2 Februari 2021

\section{ABSTRACT}

Ketepeng Cina is one of the wild plants in Indonesia which has potential as an antifungal. This is because Ketepeng Cina contains alkaloids, flavonoids, anthraquinones, triterpenoids, saponins and tannins. This study aims to determine the antifungal activity of Ketepeng Cina (Cassia alata L.) leaf extract against Trichophyton rubrum and Candida albicans. Anti-fungal testing was carried out by disc diffusion using extracts with concentrations of $20 \%, 40 \%$, $60 \%$, and $80 \%$. The test results showed an inhibition zone at all extract concentrations and the widest zone produced at a concentration of $90 \%$. This proves that the Ketepeng Cina leaf extract can inhibit the growth of Trichophyton rubrum and Candida albicans fungi. The area of the inhibition zone increases with increasing concentration because the high concentration of anti-fungal active compounds is also high. The conclusion of this study is that the Ketepeng Cina leaf extract has antifungal activity against the fungus Trichophyton rubrum and Candida albicans. The extract concentration of $90 \%$ can produce the largest inhibition zone. Based on these results, it is necessary to carry out further clinical trials on the use of Ketepeng Cina leaf extract as an antifungal agent for Trichophyton rubrum and Candida albicans.

Keywords : Cassia alata, antifungi, Trichophyton rubrum, Candida albicans

\section{PENDAHULUAN}

Berdasarkan data Profil Indonesia, 2012). Penyakit kulit karena

Kesehatan Indonesia tahun 2011, infeksi jamur banyak terjadi di diketahui bahwa penyakit kulit dan jaringan subkutan termasuk 10 besar penyakit terbanyak pada pasien non opname di rumah sakit se-Indonesia masyarakat, terlebih negara tropis seperti Indonesia. Infeksi jamur dapat disebabkan oleh jamur dermatofita dan candida albicans.

(Kementerian Kesehatan Republik 
Salah satu jamur dermatofita yang banyak menginfeksi adalah Trichophyton rubrum. Trichophyton rubrum merupakan jamur penyebab tinea pedis. Jamur ini menyerang telapak kaki dan sela-sela jari. Pertumbuhan jamur ini semakin meningkat karena kondisi telapak kaki dan sela jari yang lembab akibat bersepatu dan berkaos kaki (Nugraha and Anwar, 2015).

Candida albicans merupakan jamur pathogen penyebab kandidiasis. Jamur ini menginfeksi mulut, kulit, kuku, mulut, vagina, saluran pencernaan dan paru-paru. Infeksi jamur ini dapat bersifat akut maupun sub akut (Ningsih, Zusfahair and Mantari, 2017).

Ketepeng cina (cassia alata L) termasuk salah satu tumbuhan yang sering dimanfaatkan masyarakat sebagai obat tradisional. Tumbuhan ini banyak dijumpai di negara tropis termasuk Indonesia sebagai tumbuhan liar yang tumbuh di daerah lembab (Nugraha and Anwar, 2015). Daun ketepeng cina merupakan salah satu bagian yang sering dimanfaatkan masyarakat untuk mengobati infeksi jamur (Yacob and Endriani, 2012). Masyarakat desa Prigi Trenggalek biasanya menumbuk dan melumurkan daun ketepeng cina untuk mengobati penyakit kulit.

Daun ketepeng Cina mengandung berbagai senyawa metabolit sekunder seperti flavonoid, alkaloid, antrakuinon, saponin,dan tannin. Senyawa-senyawa ini dapat berfungsi sebagai antifungi (Octarya and Saputra, 2015). Senyawa antifungi memiliki mekanisme kerja dengan cara merusak membran sel jamur, menghambat respirasi sel jamur dan sistem enzim jamur, serta mengganggu pertumbuhan dan perkembangan spora (Aniszewski, 2007; Nugraha and Anwar, 2015; Jalianto, Khotimah and Raharjo, 2017; Ningsih, Zusfahair and Mantari, 2017).

Berdasarkan uraian di atas, maka dalam penelitian ini akan dilakukan uji aktivitas antifungi ekstrak daun ketepeng cina terhadap Trichophyton rubrum dan Candida albicans. Aktivitas ditentukan berdasarkan daya hambat pertumbuhan jamur, sehingga dapat diketahui apakah ekstrak daun ketepeng cina memiliki aktivitas antifungi.

\section{METODE PENELITIAN}

Jenis penelitian ini adalah eksperimental laboratorik dengan desain post-test only control group. Data yang diperoleh dianalisis secara deskriptif. Sampel penelitian ini adalah ekstrak etanol daun ketepeng cina (Cassia alata L.) dengan variasi konsentrasi $10 \%$, $30 \%$, 50\%, 70\%, dan 90\%. Kontrol positif yang digunakan adalah ketokenazol 1\%, sedangkan kontrol negatifnya akuades steril. Pengujian 
antifungi menggunakan difusi cakram dengan tiga kali ulangan.

Alat yang digunakan dalam penelitian ini adalah peralatan gelas, rotary evaporator, rak tabung, cawan petri, swab steril, autoclave, oven, bunsen, inkubator, dan jangka sorong. Adapun bahan yang digunakan yaitu daun ketepeng cina (Cassia alata L.), etanol, biakan murni jamur Trichophyton rubrum dan Candida albicans, PZ steril, media SDA (Saboraud Dextrose Agar), standar Mc Farland, disk blank mikrobiologi, methanol, serbuk logam $\mathrm{Mg}, \mathrm{HCl}, \mathrm{NaCl}$, $\mathrm{FeCl}_{3}$, pereaksi Dragendroff, kloroform dan asetat anhidrat, dan $\mathrm{H}_{2} \mathrm{SO}_{4}$.

\section{Prosedur Kerja}

\section{Pembuatan Ekstrak}

Ekstrak daun ketepeng cina dibuat dengan metode maserasi menggunakan pelarut etanol. Hasil maserasi disaring dan filtratnya dipekatkan menggunakan rotary evaporator. Ekstrak pekat yang diperoleh digunakan untuk uji aktivitas aantifungi dan uji fitokimia yang mengacu pada penelitian sebelumnya meliputi uji flavonoid, tannin, saponin, fenol, alkaloid, terpenoid, dan steroid (Ningsih, Zusfahair and Kartika, 2016).

\section{Pembuatan Suspensi Jamur}

Biakan murni jamur Trichophyton rubrum dan Candida albicans dikultur secara aseptis ke media
SDA. Selanjutnya biakan murni jamur diinkubasi pada suhu $37{ }^{\circ} \mathrm{C}$ selama 24 jam. Kultur murni jamur kemudian disuspensikan ke dalam $10 \mathrm{ml} \mathrm{PZ}$ steril dan dihomogenkan. Kekeruhan suspensi disesuai- kan dengan standar Mc Farland 1,0. Suspensi inilah yang akan digunakan untuk uji aktivitas antifungi.

\section{Pengujian Antifungi}

Pengujian aktivitas ekstrak daun ketepeng cina sebagai antifungi menggunakan metode difusi cakram. Masing-masing disk blank direndam ke dalam ekstrak daun ketepeng cina, kontrol positif, dan kontrol negatif selama 10 menit. Disk blank yang telah direndam lalu ditiriskan dan ditempelkan pada media SDA yang telah ditanami jamur. Kemudian dilakukan inkubasi selama 7 hari pada suhu ruang. Zona hambat yang terbentuk diukur dalam satuan milimeter menggunakan jangka sorong.

\section{Skrining Fitokimia}

\section{Flavonoid}

Sebanyak $1 \mathrm{ml}$ ekstrak ditambahkan dengan 1-2 $\mathrm{ml}$ methanol panas dan serbuk logam $\mathrm{Mg}$. Selanjutnya ditmbahkan $0.5 \mathrm{ml} \quad \mathrm{HCl}$ pekat. Apabila menghasilkan warna merah atau jingga, maka ekstrak positif mengandung flavonoid.

Tanin

Sebanyak $\quad 1.5 \quad \mathrm{ml}$ ekstrak ditambahkan beberapa tetes akuades 
panas, lalu didinginkan dan disaring. Kemudian ditambahkan 3 tetes $\mathrm{NaCl}$ $10 \%$ dan disaring. Selanjutnya ditambah- kan 2 tetes $\mathrm{FeCl}_{3}$. Apabila menghasilkan warna hijau kehitaman/ biru tua, maka sempel positif mengandung tanin.

\section{Saponin dengan metode forth}

Sebanyak $1 \mathrm{ml}$ ektstrak ditambahkan $5 \mathrm{ml}$ akuades dan dikocok selama 30 detik. Jika menimbulkan busa dan tidak hilang dalam 30 detik, maka ekstrak positif nengandung saponin. Untuk mempertahankan busa bisa ditambahkan $\mathrm{HCl} 1 \mathrm{M}$.

\section{Fenolik}

Sebanyak $1 \mathrm{ml}$ ekstrak ditambahkan 10 tetes $\mathrm{FeCl}_{3}$ 1\%. Ekstrak positif mengandung fenol apabila menghasilkan warna hijau, merah, ungu, biru atau hitam pekat.

\section{Alkaloid}

Sebanyak $1 \mathrm{ml}$ ekstrak ditambahkan 3-5 tetes pereaksi Dragendroff. Reaksi positif terjadi apabila terbentuk endapan coklat atau jingga.

\section{Terpenoid/Steroid}

Sebanyak $1 \mathrm{ml}$ ekstrak ditambahkan $0.5 \mathrm{ml}$ kloroform, lalu ditambahkan dengan $0.5 \mathrm{ml}$ asetat anhidrat. Selanjutnya campuran tersebut ditambahkan 3-5 tetes $\mathrm{H}_{2} \mathrm{SO}_{4}$ pekat melalui dinding. Apabila terbentuk warna hijau atau biru, maka ekstrak positif mengandung steroid. Sedangkan apabila terbentuk cincin warna ungu atau coklat, maka ekstrak positif mengandung triterpenoid.

\section{HASIL PENELITIAN}

Hasil uji aktivitas antifungi ekstrak daun ketepeng cina (Cassia alata L.) dapat dilihat pada Tabel 1.
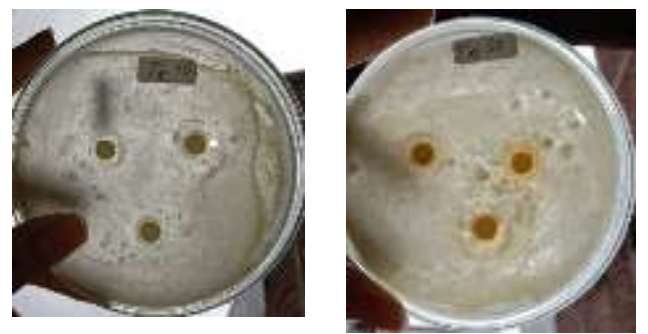

Gambar 1. Hasil Uji Aktivitas Antifungi Ekstrak Daun Ketepeng Cina

Tabel 1. Diameter Zona Hambat Pertumbuhan Jamur Trichophyton rubrum Dan Candida

\begin{tabular}{|l|c|c|}
\hline \multirow{2}{*}{ Konsentrasi } & Ratbicans \\
\cline { 2 - 3 } & $\begin{array}{c}\text { Trichophyton } \\
\text { rubrum }\end{array}$ & $\begin{array}{c}\text { Candida } \\
\text { albicans }\end{array}$ \\
\hline $10 \%$ & 9 & 10,8 \\
\hline $30 \%$ & 11.2 & 9,5 \\
\hline $50 \%$ & 13.5 & 10,3 \\
\hline $70 \%$ & 12.9 & 11,3 \\
\hline $90 \%$ & 14 & 12,4 \\
\hline Kontrol positif & 14 & 10 \\
\hline Kontrol negatif & - & - \\
\hline
\end{tabular}

Tabel 1. menunjukkan bahwa terdapat zona hambat pada variasi konsentrasi $10 \%, 30 \%, 50 \%, 70 \%, 90 \%$, dan kontrol positif, tetapi tidak pada kontrol negatif.

Tabel 2. Hasil Pengujian Fitokimia

\begin{tabular}{|l|l|c|l|}
\hline No & Uji Fitokimia & Hasil & \multicolumn{1}{|c|}{ Keterangan } \\
\hline 1 & Flavonoid & + & Berwarna jingga \\
\hline 2 & Tanin & + & Hijau tua \\
\hline 3 & Saponin & + & Berbusa \\
\hline 4 & Fenolik & + & Hijau tua \\
\hline 5 & Alkaloid & + & Endapan jingga \\
\hline 6 & Terpenoid & - & $\begin{array}{l}\text { Tidak terbentuk } \\
\text { cincin }\end{array}$ \\
\hline 7 & Steroid & - & Coklat muda \\
\hline
\end{tabular}

Catatan : (+) terdapat kandungan fitokimia (-) tidak terdapat kandungan fitokimia 
Tabel 2. menunjukkan ekstrak daun Ketepeng cina positif mengandung senyawa flavonoid, tannin, saponin, fenolik, dan alkaloid.

\section{PEMBAHASAN}

Aktivitas antifungi ekstrak ketepeng cina merupakan kemampuan ekstrak dalam menghambat pertumbuhan jamur uji. Hal ini ditunjukkan dengan adanya zona hambat (zona bening) di sekitar cakram, dimana daerah tersebut tidak ditumbuhi oleh jamur uji. Zona hambat yang terbentuk disebabkan karena adanya senyawa antifungi flavonoid, tannin, saponin, fenolik dan alkaloid (Tabel 2.) dalam ekstrak daun Ketepeng cina.

Senyawa antifungi memiliki mekanisme kerja yang berbeda-beda. Flavonoid bekerja dengan merusak atau mendenaturasi sel jamur. Gugus hidroksil pada flavonoid akan berikatan dengan fosfolipid membran sel jamur sehingga permeabilitas membran akan meningkat dan akhirnya sel menjadi rusak (Zearah, 2014). Tanin bekerja dengan menghambat biosintesis penyusun membran sel (ergosterol) (Arifin, Khotimah and Rahmayanti, 2018). Saponin mampu meningkatkan permeabilitas dinding sel jamur, karena saponin berinteraksi dengan sterol pada membran sel. Meningkatnya permeabilitas dinding sel menyebabkan cairan intrasel mengalami difusi, sehingga jamur akan mati (Septiadi, Pringgenies and Radjasa, 2013). Senyawa fenol dalam ekstrak dapat berinteraksi dengan dinding sel jamur dan menyebabkan kematian sel. Pada konsentrasi rendah senyawa fenol dapat mendenaturasi protein sel, sedangkan pada konsentrasi tinggi senyawa fenol dapat mengkoagulasi protein sel (Ngazizah, Ekowati and Septiana, 2017). Mekanisme aktivitas alkaloid sebagai antifungi adalah dengan mencegah replikasi DNA jamur, sehingga pertumbuhan jamur menjadi terganggu (Pragita et al., 2020)

Rata-rata diameter zona hambat yang diperoleh berkisar antara 9-14 mm untuk tricopiton rubrum dan 9,5-12,4 mm untuk candida albican. Kekuatan ekstrak terbagi menjadi empat yaitu : lemah (zona hambat $<1 \mathrm{~cm}$ ), sedang (zona hambat $1-1,5 \mathrm{~cm}$ ), kuat (zona hambat 1,6 - $2 \mathrm{~cm}$ ), dan sangat kuat (zona hambat $>2 \mathrm{~cm}$ ) (Rumayar et al., 2020). Berdasarkan pembagian tersebut, kekuatan ekstrak etanol daun ketepeng cina (Cassia alata L.) dalam penelitian ini termasuk kategori sedang dalam menghambat pertumbuhan jamur Trichophyton rubrum dan Candida albicans.

Perbedaan luas diameter zona hambat yang terbentuk dipengaruhi oleh konsentrasi ekstrak dan jenis 
mikroorganisme uji yang digunakan (Egra et al., 2019). Semakin tinggi konsentrasi ekstrak yang digunakan, semakin luas pula diameter zona hambat yang terbentuk. Hal ini dikarenakan semakin tinggi konsentrasi ekstrak berarti konsentrasi senyawa aktif antifungi dalam ekstrak juga semakin banyak (Yacob and Endriani, 2012). Daya hambat terbesar ditunjukkan pada konsentrasi ekstrak 90\% dengan diameter $14 \mathrm{~mm}$ untuk Trichophyton rubrum, dan 11,7 mm untuk Candida albicans.

\section{KESIMPULAN}

Kesimpulan dari penelitian ini ekstrak etanol daun ketepeng cina (Cassia alata L.) memiliki aktivitas antifungi terhadap jamur Trichophyton rubrum dan Candida albicans, sehingga dapat dimanfaatkan sebagai obat alternatif dalam mengatasi infeksi kulit.

Perlu dilakukan penelitian lanjut secara klinis mengenai daya antifungi daun ketepeng cina (Cassia alata L.) terhadap jamur Trichophyton rubrum dan Candida albicans.

\section{DAFTAR PUSTAKA}

Aniszewski, T. (2007) Alkaloid-Secrets of Life. Amsterdam: Elsevier B.V. doi: 10.1016/B978-0-444-527363.50002-7.
Arifin, Z., Khotimah, S. and Rahmayanti, S. (2018) 'Aktivitas Antijamur Ekstrak Etil Asetat Daun Mangga Bacang ( Mangifera foetida L .) terhadap Candida albicans secara In Vitro', Jurnal Cerebellum, 4(3), pp. 1106-1119.

Egra, S. et al. (2019) 'Uji Potensi Ekstrak Daun Tanaman Ketepeng (Cassia alata L) Dalam Menghambat Pertumbuhan Bakteri Ralstonia solanacearum dan Streptococcus sobrinus', Ulin - J Hut Trop, 3(1), pp. 25-31.

Jalianto, Khotimah, S. and Raharjo, W. (2017) 'Uji Aktivitas Antijamur Ekstrak Etanol Biji Buah Langsat (Lansium domesticum Corr.) Terhadap Jamur Candida albicans Secara In Vitro', Jurnal Untan, 5(1).

Kementerian Kesehatan Republik Indonesia (2012) Profil Kesehatan Indonesia Tahun 2011. Jakarta: Kementerian Kesehatan Republik Indonesia.

Ngazizah, F. N., Ekowati, N. and Septiana, A. T. (2017) 'Potensi Daun Trembilungan (Begonia hirtella Link) sebagai Antibakteri dan Antifungi', Biosfera, 33(3), p. $126 . \quad$ doi: 10.20884/1.mib.2016.33.3.309.

Ningsih, D. R., Zusfahair and Kartika, D. (2016) 'Identifikasi Senyawa Metabolit Sekunder Serta Uji Aktivitas Ekstrak Daun Sirsak Sebagai Antibakteri', Molekul, 11(1), pp. 101-111. 
Ningsih, D. R., Zusfahair and Mantari, D. (2017) 'Ekstrak Daun Mangga (Mangifera indica L.) Sebagai Antijamur Terhadap Jamur Candida albicans Dan Identifikasi Golongan Senyawanya', Jurnal Kimia Riset, 2(1), p. 61. doi: 10.20473/jkr.v2i1.3690.

Nugraha, A. and Anwar, D. (2015) 'Manfaat Daun Ketepeng Cina (Cassia alata L . ) sebagai Antifungi pada Tinea Pedis', $J$ Agromed Unila, 2(4), pp. 385388.

Octarya, Z. and Saputra, R. (2015) 'Pengaruh Jenis Pelarut Terhadap Jumlah Ekstrak Dan Daya Antifungi Daun Ketepeng Cina (Cassia Alata L.) Terhadap Jamur Trychophyton Sp', Photon: Jurnal Sain dan Kesehatan, 5(2), pp. 15-21. doi: 10.37859/jp.v5i2.581.

Pragita, A. S. et al. (2020) 'Uji Aktivitas Antimikroba Ekstrak Kulit dan Kayu Sakit Ranting Sengon Terhadap Bakteri dan Jamur, Jurnal Analis Kesehatan, 9(2), pp. 41-48.

Rumayar, R. C. et al. (2020) 'Formulasi Dan Uji Aktivitas Antijamur Sediaan Krim Ekstrak Metanol Ketepeng Cina ( Cassia alata L .) Terhadap Jamur Candida albicans', Pharmacon, 9, pp. 365371.
Septiadi, T., Pringgenies, D. and Radjasa, O. K. (2013) 'Uji Fitokimia dan Aktivitas Antijamur Ekstrak Teripang Keling (Holoturia atra) Dari Pantai Bandengan Jepara Terhadap Jamur Candida albicans', Diponegoro Journal of Marine Research, 2(2), pp. 76-84. doi: 10.14710/jmr.v2i2.2355.

Yacob, T. and Endriani, R. (2012) 'Daya Antibakteri Ekstrak Etanol Ketepeng Cina (Senna alata) terhadap Staphylococcus aureus dan Escherichia coli secara In Vitro', Jurnal Natur Indonesia, $13(1), \quad$ p. $63 . \quad$ doi: 10.31258/jnat.13.1.63-66.

Zearah, S. A. (2014) 'Antifungal and Antibacterial Activity of Flavonoid Extract from Terminalia chebula Retz. fruits', Journal of Basrah Researches, 40(1), pp. 122-131. 